\title{
GROWTH OF HETEROTROPHIC BACTERIA IN SEA WATER POLLUTED BY SURF DETERGENT
}

\author{
Dewan Pratama Novian*, Irwan Effendi, Feliatra \\ Faculty of Fishery and Marine Sciences, University of Riau, Indonesia. \\ *dewanpratama00@gmail.com
}

\begin{abstract}
The research was conducted from February 2016 to April 2017, aimed to determine the effect of adding different concentrations of detergent namely SURF on the growth of bacterial populations in the seawater column. This research used experimental method with Completely Randomized Design. Seawater samples were analyzed at Marine Microbiology Laboratory, Fisheries and Marine Faculty of Riau University. Based on the results of the study, from day 0 untill day 10 after given detergent with different concentrations, bacteria experienced a decreasing trend of growth, in day 15 untill day 20, the trend of bacterial growth contaminated by detergent with different concentration relatively increased to stagnant. Based on the result of this study the addition of different detergent concentration in each treatment affect the growth of heterotrophic bacteria population in the sea water, where the higher concentration of detergent added the lower the ability of bacteria to grow and the ability of heterotrophic bacteria to survive at different concentrations of detergent, it can be concluded that the ability of heterotrophic bacteria to grow from days 0 to 20 has decreased in each of its concentrations.
\end{abstract}

Keywords: heterotrophic bacteria, growth, seawater, Surf detergent

\section{PENDAHULUAN}

Perairan Selat Malaka yang berada di sekitar perairan Desa Kayu Ara, Kecamatan Sungai Apit, Kabupaten Siak Provinsi Riau merupakan perairan laut yang sangat dipengaruhi oleh berbagai aktivitas antara lain pelayaran, industri, aktivitas rumah tangga dan lain sebagainya. Meningkatnya aktivitas di kawasan perairan ini dapat menurunkan kualitas lingkungan perairan pantainya. Salah satu aktivitas yang dapat menimbulkan pencemaran, yang berpotensi dapat menurunkan dan merusak daya dukung lingkungan adalah buangan limbah rumah tangga yaitu limbah deterjen.

Bakteri heterotrofik merupakan komponen pada ekosistem laut yang berfungsi sebagai decomposer untuk menghasilkan mineral-mineral sebagai nutrient. Umumnya bakteri heterotrofik tergolong dalam bakteri pengurai yang berukuran halus, hidupnya singkat, dan beregenerasi cepat. Bakteri ini tidak dapat berfotosintesis atau memakan partikel organik tetapi dengan exoenzymnya dapat memecah molekul organik yang kompleks menjadi satuan kecil yang mudah diserap dan diasimilasi. Oleh karena itu, bakteri pengurai ini memegang peranan penting dalam menjaga kelangsungan siklus hidup biota di laut.

Deterjen merupakan suatu senyawa kimia yang keberadaannya sangat dekat dalam kehidupan sehari-hari. Penggunaan deterjen selain untuk mencuci pakaian, juga untuk membersihkan alat-alat kebutuhan rumah tangga dan industri. Umumnya 
komponen utama penyusun deterjen adalah Natrium Dodecyl Benzen Sulfonat (NaDBS) dan Sodium Tripolyphosphat (STPP) yang bersifat sangat sulit terdegradasi secara alamiah (Megawati, 2015).

Penggunaan deterjen yang semakin meningkat seiring dengan membaiknya pendapatan masyarakat akan berdampak pada jumlah limbah yang dihasilkan, dan bilaproses degradasi tidak berjalan seimbang akan berakibat terakumulasinya surfaktan pada badan-badan perairan, sehingga menimbulkan masalah pendangkalan perairan, terhambatnya transfer oksigen.Kondisi ini menyebabkan proses penguraian secara aerobik terganggu dan berdampak terhadap laju biodegradasi berjalan sangat lambat.

Hasil buangan deterjen ini di perairan laut dalam jumlah yang besar akan berpengaruh terhadap proses penguraian oleh bakteri dan akan mengganggu perkembangbiakan dan pertumbuhan bakteri dan mikroorganisme di perairan laut, dimana unsur- unsur yang berasal dari senyawa pada deterjen yang terakumulasi pada sedimen dan kolom air laut akan menyebabkan penurunan oksigen dan pengkayan nutrient (eutrofikasi), sehingga proses penguraian deterjen oleh bakteri yang bertahan dalam kondisi oksigen rendah akan berjalan dengan waktu yang lama.

Bakteri yang mampu menguraikan senyawa detergen adalah bakteri yang memanfaatkan senyawa tersebut menjadi sumber nutrien, sehingga hasil deterjen yang telah terdegradasi oleh bakteri, tidak menjadi polutan yang menghasilkan toksik berbahaya bagi kehidupan organisme di perairan laut.

Adanya bakteri di perairan laut, mempunyai peran yang penting dalam menguraikan limbah. Berdasarkan hal itu, maka penulis tertarik ingin mengetahui seberapa besar pertumbuhan bakteri heterotrofik yang tercemar limbah deterjen dengan dosis yang berbeda dalam skala laboratorium.

Penelitian ini bertujuan untuk mengetahui pengaruh penambahan konsentrasi deterjen berbeda terhadap pertumbuhan populasi bakteri di kolom air laut dan melihat perbandingan kemampuan bakteri bertahan dalam lama pendedahan berbeda.

\section{METODE PENELITIAN}

Waktu dan Tempat. Penelitian ini dilaksanakan pada bulan Februari 2017 sampai dengan April 2017 Pengambilan sampel air laut dari lokasi perairan Desa Kayu Ara, Kecamatan Sungai Apit, Kabupaten Siak, Provinsi Riau dan analisis sampel dilaksanakan di Laboratorium Mikrobiologi Laut, Jurusan Ilmu Kelautan, Fakultas Perikanan dan Ilmu Kelautan, Universitas Riau.

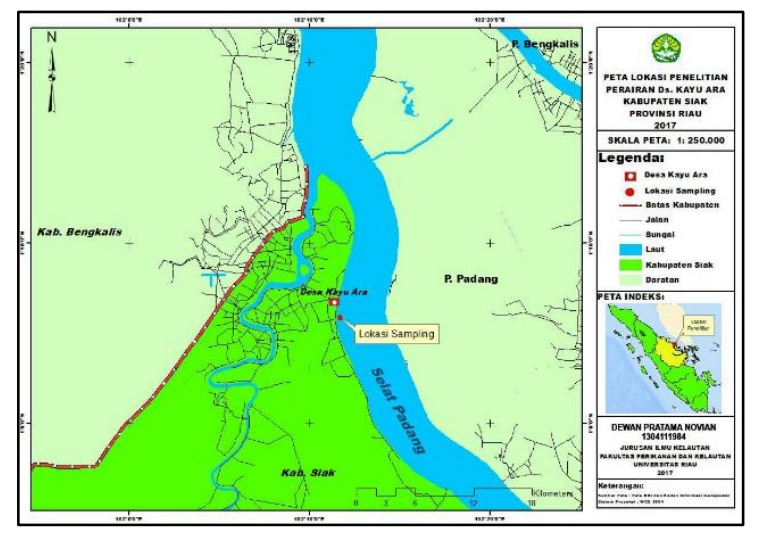

Gambar 1. Peta Lokasi penelitian 
Metode Penelitian. Penelitian ini dilaksanakan dengan menggunakan metode eksperimen dengan pola Rancangan Acak Lengkap (RAL) satu faktor terdiri dari 5 taraf yaitu S1 (konsentrasi deterjen $0 \%$ ), S2 $(0,3 \%), \mathrm{S} 3(0,6 \%), \mathrm{S} 4(0,9 \%)$ dan S5 $(1,2 \%)$. Dengan kadar deterjen S1 (0 gr), S2 (1,5gr), S3 (3gr), S4 (4,5gr), S5 (6gr). Pengujian deterjen dengan konsentrasi berbeda ini adalah untuk melihat pertumbuhan bakteri yang mampu bertahan hidup pada lama pendedahan berbeda yaitu $0,5,10,15$, dan 20 (hari). Penghitungan jumlah bakteri dilakukan dengan metoda plate count.

Data perkembangan jumlah bakteri heterotrofik dari masing-masing perlakuan disajikan dalam bentuk tabel dan digambarkan dalam bentuk grafik. Data dianalisis secara statistik dengan anova dan diuji dengan uji F (Gasperz, 1991).

\section{Persiapan Wadah Uji}

Peralatan yang digunakan disterilkan terlebih dahulu dengan menggunakan autoclave pada suhu $121^{\circ} \mathrm{C}$ selama 15 menit. Wadah uji yang digunakan adalah botol kaca (mikrokosom) bervolume 150 ml. Di laboratorium sampel air selanjutnya dimasukan ke dalam botol steril lainnya sebanyak $100 \mathrm{ml}$, dan diberi perlakuan dengan tingkat kadar deterjen yang telah ditetapkan sebagai perlakuan. Selanjutnya sampel dibalut dengan menggunakan alumunium foil untuk meminimasi efek cahaya terhadap pertumbuhan bakteri.

\section{Perhitungan Jumlah Bakteri}

Bakteri yang tumbuh diinokulasi dengan menggunakan metode sebar (Spread Plate Method). Sebanyak $1 \mathrm{ml}$ sampel dari sebuah wadah uji dimasukan ke dalam tabung reaksi yang berisi $9 \mathrm{ml}$ larutan pengencer (media cair). Lalu tabung reaksi 1 adalah pengenceran $10^{-1}$. Dari tabung raeksi 1 diambil $1 \mathrm{ml}$ kemudian dimasukan ke dalam tabung reaksi yang berisi $9 \mathrm{ml}$ larutan pengencer untuk membuat pengenceran $10^{-2}$. Begitu seterusnya sehingga pengenceran $10^{-5}$. Selanjutnya $0,1 \mathrm{ml}$ sampel dari tiap-tiap pengenceran dimasukan ke dalam media agar dan diratakan.

Petridish yang berisi media agar yang telah diratakan dengan 0,1 larutan pengencer disimpan di dalam inkubator pada suhu $30-35^{0} \mathrm{C}$ selama 24-48 jam. Kemudian koloni bakteri yang tumbuh pada media agar dihitung dengan menggunakan colony counter. Jumlah koloni yang dihitung adalah koloni yang berjumlah 30-300 koloni.

\section{HASIL DAN PEMBAHASAN}

Parameter Kualitas Perairan. Keadaan kualitas suatu perairan adalah hal yang sangat penting bagi kehidupan suatu organisme. Secara umum pertumbuhan bakteri dipengaruhi oleh parameter kualitas perairan yang meliputi suhu, derajat keasaman $(\mathrm{pH})$, salinitas dan oksigen terlarut (DO). Hasil pengukuran kualitas air di Perairan Desa Sungai Kayu Ara dapat dilihat pada Tabel 1 .

Tabel 1. Parameter Kualitas Air.

\begin{tabular}{ccccc}
\hline No & Parameter & Satuan & $\begin{array}{c}\text { Hasil } \\
\text { Pengukuran }\end{array}$ & $\begin{array}{c}\text { Baku Mutu } \\
\text { KEPMEN LH No 51 } \\
\text { Tahun 2004 } \\
\text { Alami }\end{array}$ \\
1. & Suhu & ${ }^{\circ} \mathrm{C}$ & 30 & Alami \\
2. & Salinitas & $\mathrm{Ppm}$ & 24 & $<5$ \\
3. & DO & $\mathrm{Mg} / 1$ & 6,28 & $7-8,5$ \\
4. & $\mathrm{pH}$ & - & 5 & \\
\hline
\end{tabular}


Berdasarkan Tabel 1 dapat dilihat bahwa suhu perairan $30^{\circ} \mathrm{C}$, derajat keasaman $(\mathrm{pH})$ diperoleh 5, salinitas perairan diperoleh $24 \mathrm{ppm}$ dan oksigen terlarut (DO) $6,28 \mathrm{mg} / \mathrm{l}$. Hasil pengukuran tersebut dapat disimpulkan bahwa perairan tersebut mendukung pertumbuhan bakteri karena telah memenuhi baku mutu lingkungan hidup sesuai dengan KEPMEN LH (Keputusan Menteri Lingkungan Hidup) No 51 Tahun 2004.

\section{Jumlah Bakteri Heterotrofik}

Dari hasil analisis di laboratorium, menunjukan populasi bakeri pada setiap perlakuan mengalami penurunan seiring dengan bertambahnya konsentrasi deterjen. Dalam selang waktu penelitian selama 20 hari, terlihat bahwa pertumbuhan bakteri berfluktuasi. Untuk lebih terperinci dapat dilihat pada (Tabel 2).

Tabel 2. Hasil Perkembangan Jumlah Bakteri Heterotrofik

\begin{tabular}{|c|c|c|c|c|c|}
\hline \multirow{2}{*}{$\begin{array}{c}\text { Waktu } \\
\text { Inkubasi } \\
\text { (hari) }\end{array}$} & \multicolumn{5}{|c|}{ Perlakuan Kadar Deterjen } \\
\hline & $0 \%$ & $0,30 \%$ & $0,60 \%$ & $0,90 \%$ & $1,20 \%$ \\
\hline \multirow[t]{3}{*}{ 2 } & $8,45 \times 10^{7}$ & $9,82 \times 10^{7}$ & $5,2 \times 10^{7}$ & $3,79 \times 10^{7}$ & $3,58 \times 10^{7}$ \\
\hline & $1,01 \times 10^{8}$ & $3,35 \times 10^{7}$ & $7,58 \times 10^{7}$ & $4,71 \times 10^{7}$ & $3,58 \times 10^{7}$ \\
\hline & $1,1 \times 10^{8}$ & $4,62 \times 10^{7}$ & $3,38 \times 10^{7}$ & $2,8 \times 10^{7}$ & $2,43 \times 10^{7}$ \\
\hline rata-rata & $9,87 \times 10^{7}$ & $5,93 \times 10^{7}$ & $5,39 \times 10^{7}$ & $3,77 \times 10^{7}$ & $3,2 \times 10^{7}$ \\
\hline \multirow{3}{*}{5} & $3,25 \times 10^{7}$ & $2,93 \times 10^{7}$ & $3,91 \times 10^{7}$ & $1,55 \times 10^{7}$ & $1,17 \times 10^{7}$ \\
\hline & $1,02 \times 10^{7}$ & $3,47 \times 10^{7}$ & $3,58 \times 10^{7}$ & $1,8 \times 10^{7}$ & $1,21 \times 10^{7}$ \\
\hline & $3,91 \times 10^{7}$ & $3,54 \times 10^{7}$ & $2,96 \times 10^{7}$ & $1,24 \times 10^{7}$ & $1,51 \times 10^{7}$ \\
\hline rat: & $2,73 \times 10^{7}$ & $3,31 \times 10^{7}$ & $3,48 \times 10^{7}$ & $1,53 \times 10^{7}$ & $1,3 \times 10^{7}$ \\
\hline \multirow{3}{*}{10} & $2,76 \times 10^{6}$ & $1,84 \times 10^{6}$ & $1,36 \times 10^{6}$ & $1,2 \times 10^{6}$ & $8,8 \times 105$ \\
\hline & $1,48 \times 10^{6}$ & $1,14 \times 10^{6}$ & $1,16 \times 10^{6}$ & $1,42 \times 10^{6}$ & $1,44 \times 10^{6}$ \\
\hline & $1,31 \times 10^{6}$ & $9,85 \times 10^{5}$ & $7,38 \times 10^{5}$ & $1,13 \times 10^{6}$ & $1,15 \times 10^{6}$ \\
\hline rata-r & $1,85 \times 10^{6}$ & $1,32 \times 10^{6}$ & $1,09 \times 10^{6}$ & $1,25 \times 10^{6}$ & $1,1510^{6}$ \\
\hline \multirow{3}{*}{15} & $1,43 \times 10^{6}$ & $1,08 \times 10^{6}$ & $1,24 \times 10^{6}$ & $1,34 \times 10^{6}$ & $7,75 \times 10^{5}$ \\
\hline & $1,38 \times 10^{6}$ & $1,29 \times 10^{6}$ & $1,22 \times 10^{6}$ & $1,08 \times 10^{6}$ & $1,06 \times 10^{6}$ \\
\hline & $1,17 \times 10^{6}$ & $1,47 \times 10^{6}$ & $9,19 \times 105$ & $1,33 \times 10^{6}$ & $9,83 \times 10^{5}$ \\
\hline rata-rata & $1,33 \times 10^{6}$ & $1,28 \times 10^{6}$ & $1,13 \times 10^{6}$ & $1,25 \times 10^{6}$ & $9,41 \times 10^{6}$ \\
\hline \multirow{3}{*}{20} & $2,47 \times 10^{6}$ & $1,5 \times 10^{6}$ & $1,3 \times 10^{6}$ & $1,18 \times 10^{6}$ & $8,62 \times 10^{5}$ \\
\hline & $1,28 \times 10^{6}$ & $1,17 \times 10^{6}$ & $1,11 \times 10^{6}$ & $1,01 \times 10^{6}$ & $7,36 \times 10^{5}$ \\
\hline & $1,74 \times 10^{6}$ & $1,19 \times 10^{6}$ & $6,6 \times 10^{5}$ & $7,93 \times 10^{5}$ & $4,52 \times 10^{5}$ \\
\hline rata-rata & $1,83 \times 10^{6}$ & $1,29 \times 10^{6}$ & $1,02 \times 10^{6}$ & $9,98 \times 10^{5}$ & $6,83 \times 10^{5}$ \\
\hline
\end{tabular}

Berdasarkan Tabel 2, dapat diketahui bahwa pertumbuhan bakteri heterotrofik pada selang waktu inkubasi $0,5,10,15$, dan 20 hari dengan kadar pemberian deterjen yang berbeda sebagai perlakuan, secara umum mengalami penurunan di hari ke10 pasca penanaman pada seluruh konsentrasi deterjen $(0 \%, 0,3 \%, 0,6 \%, 0,9 \%$ dan $1,2 \%)$. Setelah memasuki hari ke 15 terdapat perbedaam pertumbuhan bakteri pada masing-masing konsentrasi, untuk hari tersebut hanya bakteri pada konsentrasi $0,6 \%$ saja yang mengalami sedikit peningkatan pertumbuhan bakteri, sedangkan kadar yang lain mengalami sedikit penurunan hingga stagnan untuk pertumbuhan bakterinya.

Selang 5 hari kemudian, yaitu ketika memasuki hari ke 20 ada beberapa bakteri pada kadar $0 \%$ dan $0,3 \%$ mengalami peningkatan pertumbuhan bakteri. Namun pada kadar yang lain mengalami penurunan pertumbuhan bakteri yang relatif tinggi, hari ke 20 ini merupakan hari terakhir pengamatan jumlah bakteri heterotrofik yang tumbuh pada kadar deterjen yang berbeda. Untuk lebih jelasnya pertumbuhan bakteri dapat dilihat pada Gambar 2.

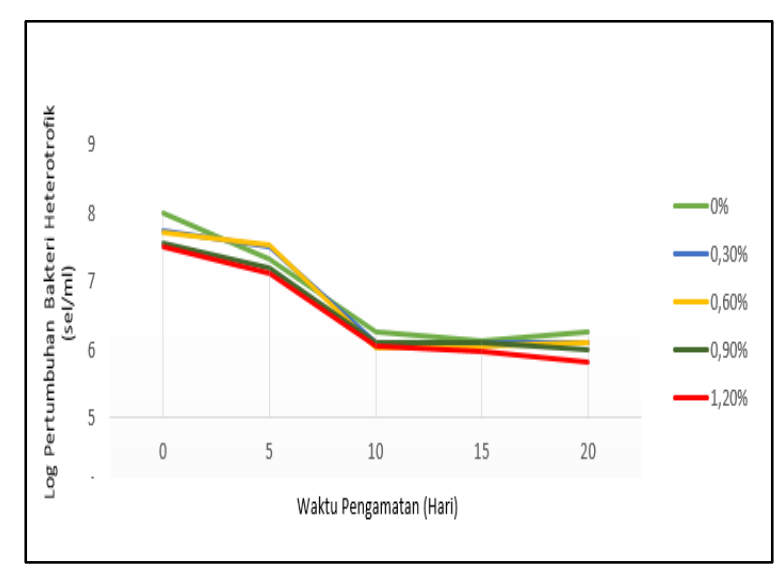

Gambar 2. Pertumbuhan bakteri heterotrofik pada kadar deterjen berbeda. 
Pertumbuhan populasi bakteri secara umum dipengaruhi oleh dominansi jenis bakteri yang dapat melakukan proses nitrifikasi, yakni perubahan oksidasi ammonium menjadi nitrit dan nitrat. Bakteri yang cenderung habitatnya menempel pada sedimen atau bahan padatan lain memiliki kecepatan pertumbuhan bakteri nitrifikasi yang lebih lambat dari pada bakteri heterotrof. Apabila pada perairan banyak terdapat bahan organik maka pertumbuhan bakteri heterotrofakan melebihi pertumbuhan bakteri nitrifikasi (Effendi, 2003).

Penurunan tegangan permukaan mengakibatkan senyawa lain yang ada di perairan dapat diabsorbsi pada permukaan interfasial yaitu permukaan antara udara dan cairan sehingga daya difusi udara (oksigen) meningkat dan pada akhirnya mampu menaikan kemampuan air untuk membasahi protoplasma mikroorganisme yang ada di dalam dinding sel, sehingga pada akhirnya sel akan mempengaruhi pertumbuhan bakteri (Suriawira, 2003).

Hingga hari ke-10 pasca pemberian kadar deterjen dengan berbagai konsentrasi berbeda, bakteri mengalami trend penurunan jumlah pertumbuhannya. Hal ini diduga karena bakteri belum mampu beradaptasi pada masukkan deterjen yang ditambahkan pada sampel air yang diambil dari perairan pesisir Desa Kayu Ara. Hal ini sesuai dengan hasil penelitian Sophia (2006) yang mengemukakan bahwa penurunan terjadi karena adaptasi bakteri terhadap deterjen, terdapat bakteri yang daya tahannya rendah. Bakteri yang tidak mampu beradaptasi akan mati, dan bakteri yang mampu beradaptasi terhadap lingkungan dalam hal ini dengan adanya penambahan deterjen akan terus hidup.

Memasuki hari ke 15 hingga hari ke 20 trend pertumbuhan bakteri yang tercemar deterjen dengan konsentrasi berbeda relatif naik hingga stagnan, hal ini diduga terkait dengan kemampuan adaptasi bakteri heterotrofik yang telah meningkat sehingga laju penurunan pertumbuhan bakteri dapat terhenti dan sedikit meningkat pada waktu tersebut. Hal ini sesuai dengan hasil penelitian Sophia (2006) yang mengemukakan bahwa setelah melakukan adaptasi, maka bakteri mulai berkembang biak. Meningkatnya pertumbuhan bakteri bisa terjadi karena bakteri sudah mampu memanfaatkan komposisi yang dikandung deterjen sebagai sumber energi untuk berkembang biak.

Menurut Palmirmo et al (2016) umumnya bakteri heterotrofik tergolong dalam bakteri pengurai yang berukuran halus, hidupnya singkat, dan beregenerasi cepat. Bakteri ini tidak dapat berfotosintesis atau memakan partikel organik tetapi dengan exoenzymnya dapat memecah molekul organik yang kompleks menjadi satuan kecil yang mudah diserap dan diasimilasi.

Dihari ke 20 pada konsentrasi deterjen $0,9 \%$ dan $1,2 \%$ mengalami penurunan pertumbuhan bakteri yang paling signifikan, konsentrasi tersebut merupakan konsentrasi deterjen yang paling tinggi ditambahkan pada sampel air laut dibandingkan dengan sampel air laut lainnya. Hal ini berbanding terbalik dengan hasil penelitian Sophia (2006) yang mengemukakan bahwa setelah hari ke 28 semakin banyak konsentrasi bakteri yang diberikan maka pertumbuhan bakteri 
setelah fase adaptasi akan semakin meningkat, hal tersebut dikarenakan bakteri yang mampu memanfaatkan deterjen sebagai bahan makanan akan tumbuh lebih pesat.

Waluyo (2004) menyatakan adanya zat-zat hasil metabolisme yang mungkin beracun dapat menghambat pertumbuhan bakteri. Menurut Dwijoseputro (1990), penyebab kematian bakteri juga bisa disebabkan karena nilai ekskresi bakteri itu sendiri selama penelitian berlangsung. Hasil ekskresi yang terus menumpuk dapat mengganggu perkembangan dan pertumbuhan bakteri heterotrofik.

\section{KESIMPULAN}

Dari hasil pengamatan dapat disimpulkan bahwa:

1. Pengaruh penambahan konsentrasi deterjen berbeda terhadap pertumbuhan populasi bakteri dapat diketahui bahwa penambahan kadar deterjen pada setiap perlakuan berpengaruh terhadap pertumbuhan populasi bakteri heterotrofik didalam air laut dimana semakin tinggi konsentrasi deterjen yang ditambahkan semakin rendah kemampuan bakteri untuk tumbuh.

2. Kemampuan bakteri heterotrofik bertahan pada konsentrasi deterjen berbeda disimpulkan bahwa kemampuan bakteri heterotrofiik untuk tumbuh dari hari $0-20$ mengalami penurunan di setiap konsentrasinya hingga hari ke 20.

\section{SARAN}

Perlu ada penelitian lanjutan
mengenai jenis bakteri yang mampu
menguraikan deterjen. Selain itu
diharapkan untuk melakukan pengukuran
kadar deterjen agar dapat mengetahui
deterjen mana yang paling mudah untuk
diuraikan oleh bakteri heterotrofik.

\section{DAFTAR PUSTAKA}

1. Megawati. I. A. 2015. Uji Toksisitas Deterjen Terhadap Ikan Nila. Fakutas Ilmu Kelautan dan Perikanan Universitas Maritim Raja Ali Haji.

2. Effendi, H. 2003. Telaah Kualitas Air Bagi Pengelolaan Sumber Daya dan Lingkungan Perairan. Penerbit Kanasius, Jogjakarta.

3. Suriawira ,U. 2003. Mikrobiologi Air. PT. Alumni Bandung. 59 hal.

4. Sophia. A. M. 2006. Pertumbuhan Baktri Heterotrofik Pada Air Laut Tercemar Deterjen Anionik. Skripsi. Pekanbaru: Universitas Riau.

5. Palimirmo. F. S., A. Damar dan H. Effendi. 2016. Dinamika Sebaran Bakteri Heterotrofik di Teluk Jakarta. Jurnal Ilmu Pertanian Indonesia, 21(1): 26-34. 